\title{
WEATHERING RIND AGE ASSIGNMENT OF NEOGLACIAL DEPOSITS IN THE OKSTINDAN MOUNTAINS, NORTHERN NORWAY
}

\author{
W. C. Mahaney \\ Quaternary Surveys, 26 Thornhill Ave., Thornhill, Ontario, Canada, L4J1J4 and Department of Geography, \\ York University, 4700 Keele St., N. York, Ontario, Canada, M3J 1P3; e-mail: arkose41@gmail.com
}

\begin{abstract}
Previous soil stratigraphic analysis of soil morphogenesis in the Okstindan Mountains established a Late Neoglacial soil evolutionary sequence based on historically monitored and radiocarbon-dated moraine positions over the last $\sim 3.0$ cal yr BP. Thus pedon evolution ranged from $\mathrm{C} / \mathrm{Cu} \rightarrow \mathrm{Ah} / \mathrm{Cox} / \mathrm{Cu} \rightarrow$ pedostratigraphic succession of $\mathrm{Ah} / \mathrm{C} / \mathrm{Cu} / \mathrm{Lb} /$ $\mathrm{Cub} / \mathrm{Ahb} / \mathrm{Coxb} / \mathrm{Cub}$ profiles with a maximum rind weathering time of $\sim 1.0 \mathrm{kyr}$. Following successive retreat phases of Neoglacial ice, weathering rind development continued apace on moraines, each rind population recording weathering time following successive glacier stillstands. The age of the youngest deposits falls within the period 1900-1910 AD, or the last $100 \mathrm{yrs}$, with variable moraine positions all documented by historical depictions of the position of the Austre Okstindan glacial lobe prior retreating to its present position. The next older group of deposits is considered to have been emplaced near the end of the LIA or around $1800 \mathrm{AD}$, with time of rind development set at $200 \mathrm{yr}$, possibly older. The oldest moraine set within the late Neoglacial sequence lies atop a pedostratigraphic column, the uppermost soil radiocarbon dated at $\sim 1.0 \mathrm{yr}$ BP. Given the range of mean rind development across this threshold of deposits, from $0.22 \pm 0.03 \mathrm{~mm}$ in the inner group, $0.66 \pm 0.07 \mathrm{~mm}$ in the middle group, to $1.38 \pm 0.15 \mathrm{~mm}$ in the outer, older group, it is clear that finite measurements at several sites within a suite of deposits, some dated by radiocarbon, can evenly discriminate between deposits in a glacial succession.
\end{abstract}

Key words: Little Ice Age; Okstindan Neoglacial record; weathering rinds.

Manuscript received 21 July 2016, accepted 10 November 2016

\section{INTRODUCTION}

Weathering rinds have been used in many mountain areas, mainly to provide relative age control on glacial deposits ranging across much of the Pleistocene (Sharp, 1969; Birkeland, 1973, 1999; Beschel, 1971; Mahaney, 1973, 1978, 1990; Chinn, 1981; Mahaney and Spence, 1984; Mahaney et al., 1999, 2012a; Colman, 1981; Colman and Pierce, 1981; Laustela et al., 2003; Gurney and Bartsch, 2005; and Mahaney and Keiser 2012). Recently, strides have been made with isotope dating of weathering fronts in clasts (Pelt et al., 2008). Others have probed clast coatings for a variety of reasons, specifically to obtain archaeological data (Dorn, 2009), weathering chemistry and mineralogy (Dixon et al., 2006; Oguchi, 2013; Mahaney, 2015). Still others have analyzed weathering rinds focusing on biogenic processes (Etienne, 2002; Mahaney et al., 2013a), relation between soils/paleosols and rinds (Mahaney et al., 2013b, Mahaney and Hancock, 2015), reconstruction of paleoclimatic/weathering trends over post-Oligocene time (Mahaney and Schwartz, 2016), and determination of rind thickness in meteorites on Mars stressing their potential to house extant and fossil microbes (Mahaney et al., 2012b). As demonstrated by numerous re- searchers, weathering rinds carry complex and long-lived records of clast weathering, development of biogenic compounds, and genesis of various secondary minerals including incorporation of allochthonous materials. Often clast weathering rinds form micro weathering zones that can be correlated with associated in situ paleosols (Mahaney et al., 2013a; Mahaney and Schwartz, 2016).

Previous research (Mahaney and Hancock (2015) was undertaken to determine if topographic/stratigraphic setting, weathering characteristics and soil/paleosol properties could be used to elucidate information on paleoenvironment and age of a chronosequence of surface and buried soils in moraines and outwash in the foreland of the Austre Okstindan lobe. Deposits ranging in age from Middle to Late Holocene, [i.e. Neoglacial inclusive of Little Ice Age (LIA)], have weathered under alpine and subalpine vegetation in the Okstindan Mountains of central-north Norway $\left(66^{\circ} \mathrm{N}\right)$, in garnet-mica-schist (Bjerkgĺrd, 1995; Geological Survey of Norway, 2007). The geochemical record and geological mapping previously published by the Norwegian Geological Survey detail a uniform parent material in these deposits; thus, surface clast lithologic uniformity makes it possible to construct a rind curve useful in judging weathering rate and 


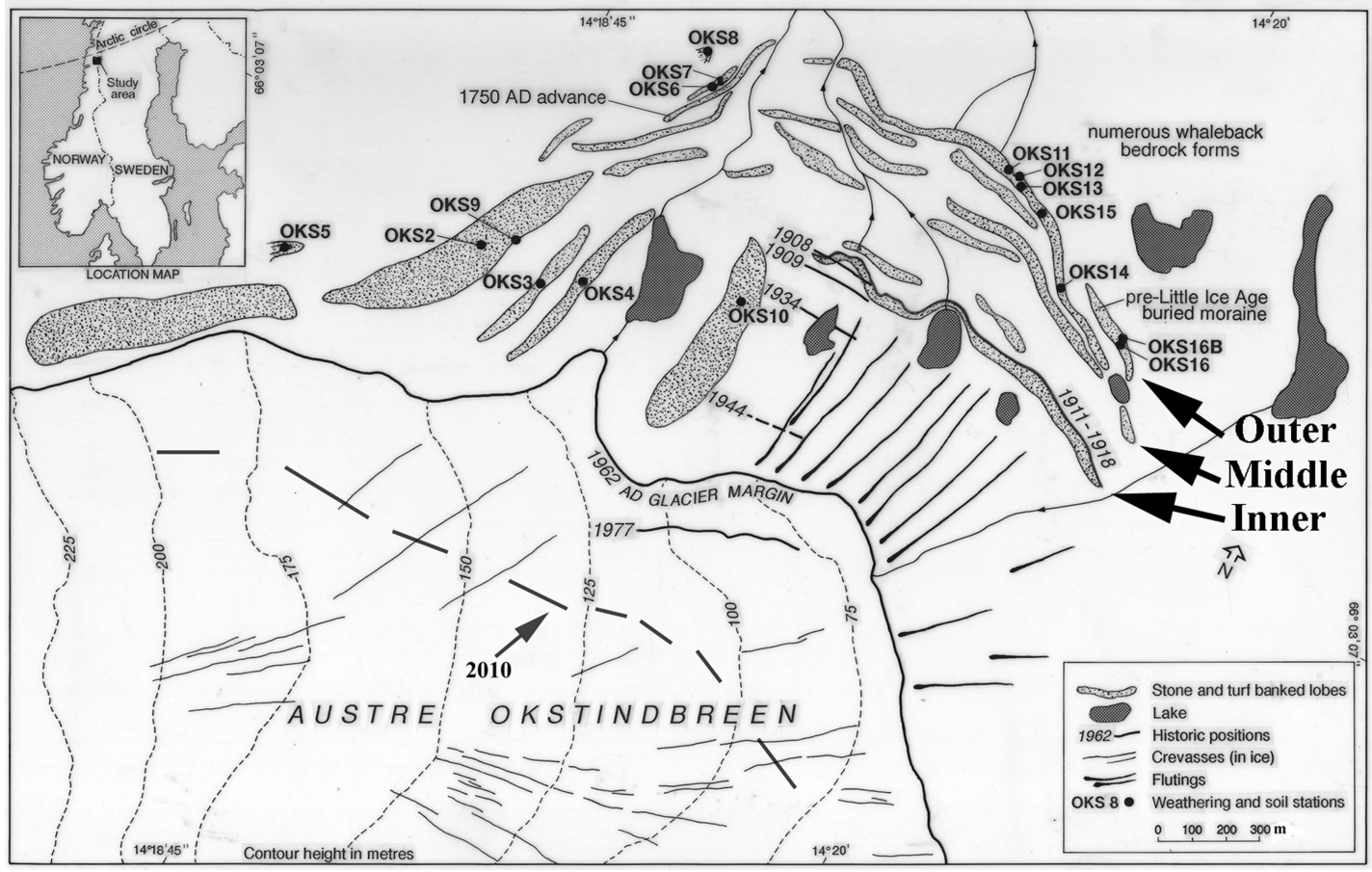

Fig. 1. Location of LIA moraines and sites, Austre Okstindbreen lobe, Nordlands. The inner, middle and outer moraine groups are marked along with the approximate moraine terminus in 2010.

age of substrate. Whereas weathering rind growth in Neoglacial deposits is relatively unknown and unstudied, data from the Tärna Glacier area of Sweden (Mahaney unpublished; Mahaney and Kalm, 2012), Iceland (Etienne, 2002), the Wind River Range of Wyoming, (Mahaney, 1978). Teton Mountains (Mahaney and Spence, 1984) and Mount Kenya (Mahaney, 1990), suggest that while lithology provides important constraints on weathering, climate is the most important control of rind and soil genesis. On the Okstindan Massif, with a normalized lithology and minor radiocarbon control it is possible to assess rind development in a high latitude maritime climate.

\section{MATERIALS AND METHODS}

Rock samples of pebble grade were selected from key sites (Fig. 1) on moraines ranging from $\sim 1 \mathrm{ka}$ cal yr BP to near the present limit of the Austre Okstindbreen Glacier in Nordland, the youngest clasts deposited $<100$ yr. Pebbles at each site were split with a rock hammer and rinds measured by color or oxidation effects to the nearest $\mathrm{mm}$. Clasts from the oldest moraine have a maximum age of $970 \mathrm{cal} \mathrm{yr} \mathrm{BP,} \mathrm{the}$ age of moraine emplacement calculated from an underlain peat bed (Lb horizon in a Fibrisol, NSSC, 1995; organic soil, CSSC, 1998). Given that the peat sample collected for dating came from the middle of the Fibrisol, it may in fact be somewhat older than the younger (upper) part of the peat bed. If so, it is possible the overlying moraine emplacement (OKS16upper) is close to 450 cal yr BP ( 1500 AD) start up time of the LIA. Weathering rind measurements were made in 1993, the last year of the Tarna-Okstindan project.

To show extremes of rind growth, samples were collected from several surface deposits in the outer moraine group (Fig. 1) of late Neoglacial age. Similar sites were se- lected within the middle and inner late Neoglacial moraine groups as shown on Figure 1. Groups of rind mean thicknesses for each station within each of the three groups of variable age were analyzed, with means and statistical ranges calculated for each group. Measurement of lichen growth follows from the pioneering work of Beschel (1950) with measurements as documented here following methods in Mahaney (1990).

\section{RESULTS}

\section{Deposit age determination}

Ages of deposits were determined from soil properties detailed in Mahaney and Hancock (2015). The soils in the sequence range from a stack of Cryorthents (Regosols in the Canada soil system, CSSC, 1998; Entisols in the US Taxonomy (NSSC, 1995) (OKS16, lower and upper pedons), separated by a Fibrisol (Histosol) Lb horizon, its peat dated to $1100 \pm 70 \mathrm{yr}$ BP (BGS-1447) calibrated to $970 \mathrm{cal}$ yr BP; the lower and upper beds of the $\mathrm{Lb}$ horizon remain undated. The OxCal v. 4.2.3 calibration of this date is $970 \pm 720 \& 1118 \mathrm{cal}$ yr BP (Reimer, 2004; Bronk Ramsey, 2005). The oldest soil in the sequence is the lower OKS16 $(\mathrm{Ahb} / \mathrm{Cb})$ soil formed in till of presumed Early Neoglacial age, emplaced prior to the deposition of fresh unweathered glacial sediment (Cub) followed by buildup of peat (Lb) comprising the middle peat beds of OKS16. The overlying peat in the middle unit (Lb horizon) signals a buildup of organic material under cool climatic conditions, presumably during a later phase of Neoglaciation (ca. $\sim 1 \mathrm{ka}$ ). The Lb horizon was buried by moraine emplacement at $\sim 1$ kyr followed by soil genesis in the moraine bed of the upper pedostratigraphic stack surface that produced an Ah/Cox/Cu profile (Mahaney and Hancock, 2015). 


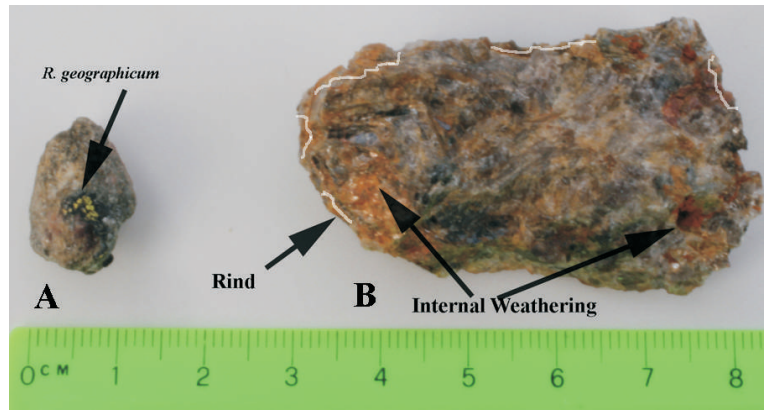

Fig. 2. Comparative garnet-mica clasts showing a fresh pebble (A) from the Inner Moraine Group showing zero rind but with a small ( $\sim 1 \mathrm{~mm}$ dia) thallus of $R$. geographicum; and maximum rind development on a clast (B) from the Outer Moraine Group, maximum $\sim 1.5 \mathrm{~mm}$ thickness outlined with a discontinuous border, minimum thickness $0 \mathrm{~mm}$. Some internal mica minerals show thin $<1$ $\mathrm{mm}$ thick rinds and others showing wider areas of $\mathrm{Fe}+3$ weathering.

Rinds measured from clasts in the surface of OKS16 were compared with mean rind measurements in sites OKS5, 6, 7, $8,16,16 \mathrm{~B}$ and $16 \mathrm{~B}(2)$ (see Fig. 1), all considered to have an age of $\sim 1$ kyr or younger.

The middle group of deposits, comprising surface clasts in sites OKS 11, 12, 12(2) 13, 14 and 15 (Fig. 1 for location), are considered to have near terminal LIA ages of $\sim 200 \mathrm{yr}$ or older. Soils in this intermediate group of deposits have profiles similar to what exists in the surface of the pedostratigraphic succession carrying $\mathrm{OKS} 16$, an $\mathrm{Ah} / \mathrm{Cox} / \mathrm{Cu}$ profile but with significant soil property differences. The profile in OKS16, thicker than OKS12 by $13 \mathrm{~cm}$, carries a higher concentration of $\mathrm{Fe}$ extracts, specifically twice the concentration of ferrihydrite and a near 50\% increase of oxihydrites of goethite and hematite (Mahaney and Hancock, 2015), all of which indicate an age difference of several centuries. Moreover, the inverse relationship between illite and vermiculite, specifically the slow degradation of illite and production of vermiculite from pre-LIA to post LIA (i.e. OKS16 OKS12) time measured from clay mineral assemblages supports the Fe extract concentration data.

Compared with sites located within the 1911-1918 historically-designated moraines near the present Okstindbreen terminus, this inner belt of moraines, including sites OKS 2, $3,4,9$ and 10, are approximately $\sim 100$ yrs old and carry thin weathering profiles with $\mathrm{C} / \mathrm{Cu}$ or $\mathrm{C} / \mathrm{D}$ profiles, coarse textures, no soil structure, near nil Fe extracts and clay mineral compositions with higher illite and nil vermiculite (Mahaney and Hancock, 2015). Each moraine group is recognized by degree of soil development as follows: outer group-Ah/ $\mathrm{Cox} / \mathrm{Cu}$, often with a pedostratigraphic complex extending $>1$ ka based on one ${ }^{14} \mathrm{C}$ date discussed above; middle group $\mathrm{Ah} / \mathrm{Cox} / \mathrm{Cu}$ (without a pedostratigraphic complex), and an inner group comprising either $\mathrm{C} / \mathrm{D}$ or $\mathrm{C} / \mathrm{Cu}$ soil profiles depending upon the texture of the parent substrate.

\section{Rind data}

Rinds (Fig. 2) were measured at five sites in the inner moraine loop, six sites within the middle moraine group and seven sites in the older deposits with two repeat rind popula-
Table 1

Mean rind thickness for the inner (100 yr), middle $(\sim 500 \mathrm{yr})$ and outer $(\sim 1 \mathrm{k} \mathrm{yr})$ sites in the foreland of the Austre Okstinbreen Glacier lobe, north Norway

\begin{tabular}{|c|c|c|c|c|c|c|}
\hline \multirow{4}{*}{ Group } & Sitea & $\begin{array}{c}\text { Mean } \\
\text { Rind } \\
(\mathrm{mm})\end{array}$ & $\begin{array}{c}\text { Standard } \\
\text { Deviation }\end{array}$ & Fresh/50 & $\begin{array}{c}\text { Group } \\
\text { Mean } \\
(\mathrm{mm})\end{array}$ & $\begin{array}{c}\text { Standard } \\
\text { Deviation }\end{array}$ \\
\hline \multirow{5}{*}{ Inner } & 2 & 0.22 & 0.02 & $23 / 50$ & & \\
\cline { 2 - 7 } & 3 & 0.21 & 0.02 & $24 / 50$ & & \\
\cline { 2 - 7 } & 4 & 0.19 & 0.03 & $21 / 50$ & & \\
\cline { 2 - 7 } & 9 & 0.20 & 0.02 & $28 / 50$ & & \\
\cline { 2 - 7 } & 10 & 0.23 & 0.01 & $18 / 50$ & 0.21 & 0.03 \\
\hline \multirow{5}{*}{ Middle } & 11 & 0.57 & 0.05 & $16 / 50$ & & \\
\cline { 2 - 7 } & 12 & 0.60 & 0.04 & $14 / 50$ & & \\
\cline { 2 - 7 } & 13 & 0.66 & 0.05 & $17 / 50$ & & \\
\cline { 2 - 7 } & 14 & 0.65 & 0.04 & $13 / 50$ & & \\
\cline { 2 - 7 } & 15 & 0.62 & 0.03 & $15 / 50$ & 0.62 & 0.07 \\
\hline & 5 & 1.30 & 0.08 & $8 / 50$ & & \\
\cline { 2 - 7 } & 16 & 1.40 & 0.08 & $5 / 50$ & & \\
\cline { 2 - 7 } & $16 \mathrm{~B}$ & 1.41 & 0.07 & $6 / 50$ & & \\
\cline { 2 - 7 } & $16 \mathrm{~B}(2)$ & 1.39 & 0.12 & $4 / 50$ & 1.38 & 0.17 \\
\hline
\end{tabular}

Sites are on Fig. 1. Mean rind thickness for each site was calculated by summing clast rim discoloration $/ 50$. The number of fresh clasts with no outer rim weathering decreases with time from near $50 \%$ in the inner group, and $\sim 30 \%$ in the middle population, to $\sim 10 \%$ in the outer group. Weathering internal to the clast along fracture planes was not measured. Group means from inner to outer populations follows a linear trend with tight standard deviations (cf. Fig. 3).

tions at sites marked (2). Only samples of garnet-mica-schist were measured and any samples showing weathering within foliation planes were discarded, although mica clusters within clasts and weathered fracture faces (Fig. 2) were noted but not measured. The means of each sample population of 50 clasts, at sites within each sample group, were subjected to calculation of statistical ranges of the means within each moraine group as shown in Table 1 . The total minimum rind count within these three sample populations is zero, conforming to previous measurements (Mahaney, 1978; Mahaney, 1990) of Neoglacial-age clasts elsewhere in the mountains of the world. Minimum rind growth is only registered when the entire clast is weathered with variable thickness, which requires considerable time beyond the range of Neoglacial-age sediment. The counts of fresh/50 tallies the number of fresh, that is, zero rind growth, which in this study, varies from near $50 \%$ on the inner moraine sites, $\sim 25-\sim 35 \%$ on the middle moraines, to $\sim 4-\sim 15 \%$ on the outer group.

Means, calculated for each site within the three sample groups - inner, middle and outer - were made from rinds measured to the nearest $\mathrm{mm}$. These means were then plotted within the three estimated age groups of deposits (Fig. 3). Mean measurements for sites within each of the three deposit groups show a narrow cluster of mean measurements at $\sim 100$ $\operatorname{yr}(\bar{x}=0.22 \mathrm{~mm} \pm 0.03)$, widening somewhat at $\sim 200 \mathrm{yr},(\bar{x}=$ $0.66 \mathrm{~mm} \pm 0.07)$, widening even more at $\sim 1 \mathrm{kyr}(\bar{x}=1.38 \mathrm{~mm}$ \pm 0.17 ) suggesting that with increasing age, differential weathering processes tend to produce variable ranges of mean values for individual sites within a single stratigraphic unit (i.e., the same relative age group). Because the history of 


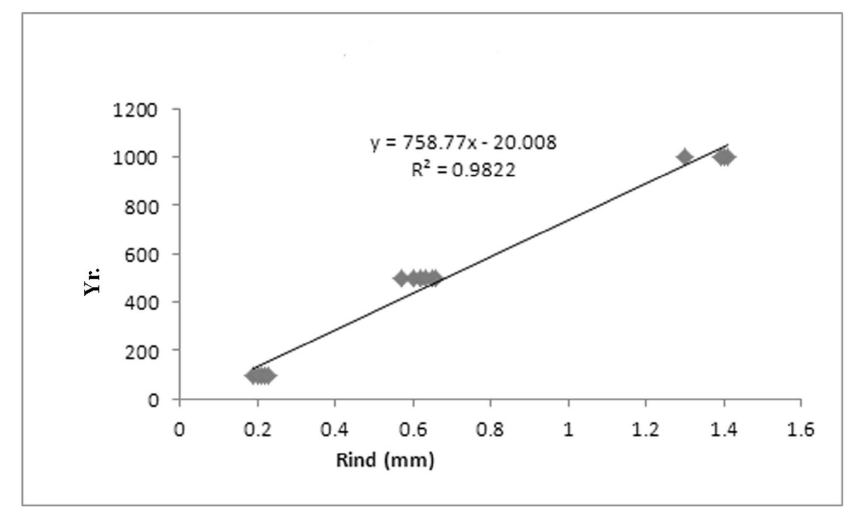

Fig. 3. Mean rind values per site vs age regression, $\sim 1 \mathrm{kyr}$ to present, Austre Okstindbreen lobe, Nordlands. Plus and minus figures are ranges of mean values for populations of: inner group $=250$; middle group $=300$; outer group $=350$.

individual clasts is unknown, it is possible that clasts nested with fines and or colloidal organics may have positions advantageous to retention of heat and moisture thus leading to a greater variability in rind thickness.

The clast shown in Fig. 2 (A), from OKS3, one of the oldest deposits within the inner moraine group, while not carrying a weathering rind, does carry a visible small thallus of Rhizocarpon (spp. unknown but possibly $R$. geographicum) with a black fruiting body visible in a small micro-tank depression in the clast surface. Whereas it is known that $\sim 35 \mathrm{yrs}$ are required for spores of the genus Rhizocarpon to become visible at some European localities (Runemark, 1956), this lichen is comfortably resident within the post-LIA moraine group dated historically to well within the last century. Lichen visibility next to existing ice is rarely recorded but in the Wind River Mountains of western Wyoming, visible lichen thali are seen within 25-30 yr of ice withdrawal (Mahaney, 1978, 1987), and on Mt. Kenya within 20 yr (Mahaney, 1990; Spence and Mahaney, 1988). The visibility/age difference is probably attributable to climate and moisture availability.

The rind measurements summarized in Fig. 3 were all taken from populations of 50 clasts $(n=50)$ at specified sites shown on Fig. 1, all from schist. Because schist contains narrow foliation planes that allow ingress of moisture and heat at faster rates than with other lithologies such as granite and basalt, one might expect more rapid rind growth such as measurements made in the foreland of the Austre Okstindbreen.

\section{DISCUSSION}

\section{Paleosols and soils}

For the purposes of this paper, Neoglacial age refers to deposits younger than ca. $5000 \mathrm{yr}$ BP. The precise time of the onset of Neoglaciation is unknown; however, as demonstrated by Mahaney and Hancock (2015), it must be older than $\sim 1000 \mathrm{yr} \mathrm{BP}$, and most probably is ca. $+3000 \mathrm{yr} \mathrm{BP}$. A similar estimate for the Austre Okstindbreen was arrived at by Griffey and Worsley (1978), and in the Rocky Mountains of Wyoming by Mahaney (1978). As postulated by Ellis (1979), based on dates from buried soils documenting the ini- tiation of solifluction, it may well be that the initiation of Neoglaciation is much older, perhaps even of Middle Holocene age. Similar age control resulted from work by Elliott and Worsley (1999) on turf-banked lobes, and from timberline shifts in the nearby Tärna area by Earl-Goulet et al. (1998).

Paleosol and soil profiles in the sequence, shown in Mahaney and Hancock, 2015; Fig. 3, range from Cryorthents (OKS16, lower, middle and upper, and OKS12), to weathering profiles with $\mathrm{C} / \mathrm{Cu}$ horizonation (inner group). The oldest paleosol in the sequence is lower OKS16 $(\mathrm{Ahb} / \mathrm{Cb})$ that formed in till of presumed early Neoglacial age prior to the deposition of fresh unweathered glacial sediment ( $\mathrm{Cub}$ ) and peat ( $\mathrm{Lb}$ ) comprising the middle beds of OKS16. The overlying peat in the middle unit (Lb horizon) signals buildup of organic material under cool climatic conditions, presumably during a later phase of Neoglaciation (ca. $\sim 2 \mathrm{ka}$ ). Clasts within the Ah horizon of the lower paleosol were not measured because their rind records would provide only a tentative fit to the surface rind curve. The middle paleosol in OKS16 does not contain clasts of pebble grade size and hence cannot be fitted into the rind-time sequence described here. The OKS12 soil, from the middle moraine group in the sequence, carries a similar morphology to OKS16 (upper). The term soil is used for those pedons within the Neoglacial surface exposures; paleosol is reserved for older buried soils formed presumably under cooler/drier climate of the SubBoreal and early-stage Sub-Atlantic.

The Lb horizon was buried by moraine emplacement at $1100 \pm 70 \mathrm{yr}$ BP (BGS-1447) calibrated to $970 \mathrm{cal}$ yr BP; the lower part of the Lb horizon remains undated. The OxCal v. 4.2 .3 calibration on this date is $970 \pm 720 \& 1118$ cal yr BP (Reimer, 2004; Bronk Ramsey, 2005). This date is based on the whole-soil sample, so it could be older than the actual time of burial. However, because the mean residence time (MRT) of radioactive carbon is unknown, it is impossible to be certain about the differences between ${ }^{14} \mathrm{C}$ age and the true time of burial. As explained previously, we (Mahaney and Hancock, 2015) removed the humic acid fraction despite the fact the chemical data (reported later) did not suggest downward leaching, which might tend to produce younger ${ }^{14} \mathrm{C}$ ages.

\section{Rinds}

As with soils in moraines, rind development starts with deposition of sediment, assuming clasts are fresh and without chemical mobilization of pebble surfaces. The time-zero for fresh clasts may be offset by the presence of reworked or preweathered clasts that owe their origin to a previous weathering event followed by reincorporation into glacier loads. Such preweathered clasts, depending on the magnitude of anomalous rind thickness, may significantly skew mean rind thickness measurements, which is why calculations of standard deviations around the mean are important to make after rind thickness is measured in the field. Standard deviations calculated for the inner moraine group are within $0.04 \mathrm{~mm}$ of the mean, increasing up to 0.12 in the middle group, topping off at $0.28 \mathrm{~mm}$ for the older group of samples. Because radiocarbon ages for sites on individual moraines are not avail- 
able, it is not possible to construct an age/thickness curve for the area showing means and standard deviations for each site. Calculation of mean rind thickness for sites within each deposit group (Fig. 3) gives a measure of the increasing range of rind thicknesses within each stratigraphic group.

Rind development may be slow or fast depending upon lithological and environmental stresses, latter constraints involving the subaerial atmosphere and biogenic influxes (Mahaney et al., 2012b), which mainly control moisture and heat, along with organic compounds that supply kinetic energy to the rock surface. While soils develop an epipedon (Ah/B horizon), a thermodynamic engine controlling the sum total of inputs and outputs of matter and energy to the weathering system, clasts in a deposit surface suffer the same overall effect, but with similar chemical mobilizations on a microscale. As a result the more reactive/soluble rock constituents are lost or recombine to form new compounds in residence with more resistant minerals. The effects in both systems are similar, only the scale differing with the soil slowly developing into a paleosol, and the weathered clast developing weathering zones within the rind, weathered micro-sectors as it were, mimics of horizons within the soil/paleosol system, such as, in other older weathering/soil/paleosol systems (Mahaney et al., 2013a).

Rind geometry is anything but spherical (Fig. 4), except in anomalous cases (Sharp, 1969), and possibly produced by a near spherical or elliptical clast at start up time. Of the 700 clasts measured here, as shown in Table 1, virtually all fall into angular and subangular groups, only the occasional round pebble (see A in Fig. 2), as one of the fresh/50 group, takes on a spherical shape. As indicated in Fig. 4, a hypothetical angular clast in two dimensions is shown to exhibit a range of rind thickness, from nil to $\sim 2 \mathrm{~mm}$, with various thickness departures along other segments of the clast. Eventually, after many trials with the population of clasts reported here, it became clear that rind analysis, if applicable to age assignment, should include maximum and minimum measurements within a population $\mathrm{n}=50$ at each weathering station (Fig. 1). Thus, mean maximum and mean minimum calculations with standard deviations for each suite of calculations, first used in the Wind River Mountains of Wyoming (Mahaney, 1978) proved useful to tighten relative age controls on deposits within a glacial deposit sequence. Along with this came the realization that within the Rocky Mountains, at type localities in the Wind River Mountains (Mahaney, 1978), and on Mt. Kenya (Mahaney, 1990), that mean minimum rind measurements could be used to differentiate Neoglacial from late Pleistocene surfaces, mean minimum rinds nil on the younger sites, positive on the older deposits.

Lithology largely controls rind color (Mahaney et al., 2012a) with Fe, Si and C dominating the chemical matrix that forms the rind, and, of the three elements Fe is usually the main constituent forming various oxides and hydroxides. Several attempts to equate rind color (Oyama and Takehara, 1970) with the colors of horizons within associated paleosols (Mahaney et al., 2012a and 2013a), using either field colors or published sample colors show similarities between the two sample groups: brownish-black (10YR hue, with value/chroma of $3 / 1-2 / 3$ ) colors grading through various value/chroma changes of brown to dull yellowish brown (10YR4 to 6

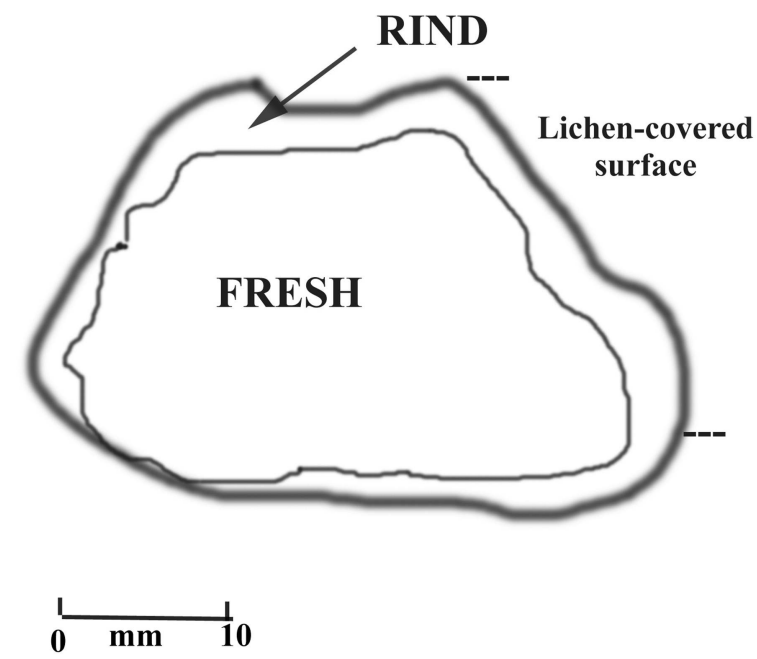

Fig. 4. Hypothetical rind diagram showing variable rind thickness vs fresh clast. Older clasts may have a continuous but variable rind so that maximum and minimum values are positive; with younger clasts part of the rind may be fresh yielding a nil minimum value. Even clasts in young deposits may be large enough so that weathering is pronounced on the surface in contact with the subaerial atmosphere, minimum on the underside facing into a soil/ paleosol profile.

hues), to near light grey to yellow (2.5Y hue) in fresh clast/ soil $\mathrm{Cu}$ horizons. Thus, at least in some instances, color gradations in rinds follow similar ranges of hue in pedons.

Clay minerals, either of autochthonous or allochthonous origin, make up variable atomic volumes of material within rinds, and in some cases (Lebedeva et al., 2007) comprise the greatest volume of material after millions of years of weathering (Mahaney, 1990; Mahaney et al., 2012a). Assuming loss of material, rinds in polar desert areas of Antarctica, with thicknesses of $7 \mathrm{~mm}$ comprise $7 \times 10^{6} \mathrm{~nm}$ of atomic space covering climatic changes over immense periods of time (Mahaney and Schwartz, 2016). Theoretically, at least, Fe-rich rocks like gabbro and basalt (Sak et al., 2004) should produce thicker rinds over similar time spans and in similar climatic/biogenic conditions when compared with granitic and rhyolitic lithologies, given variations of $\mathrm{FeO}$ between the two rock suites. This is not always the case, however, since the biogenic factor may include microbes which are thought to control redox potentials, possibly controlled more by age than by external heat and moisture. Microbes in Mn nodules recovered from Andean paleosols are correlates of clastic rinds in paleosol surfaces and are known to contain prolific microbes (Mahaney et al., 2013c). Because microbes are known to occur in paleosols in middle latitude mountains (Mahaney et al., 2013a) and in Miocene paleosols in Antarctica (Mahaney, 2015), it is likely both extant and fossil microbes are present in weathering rinds. When compared with carbonates, silicates dominate the velocity race in rind genesis simply because carbonates, without appreciable Fe, are nearly totally soluble producing nil weathered crust, only producing changes in pebble sphericity with age. Given the young age of clasts in the Okstindan Neoglacial sequence, no attempt was made to study pebble clasts searching for microbes. 
Since the work of Nelson (1954) most workers (Sharp, 1969; Birkeland, 1973; Mahaney, 1978) initially concentrated on measurements of rind thickness, taking the mean of a population of 50 samples as a measure of weathering time following deposition. Age estimates from rind thickness are subject to certain uncertainties mainly caused by erosion at the rind surface and/or sealing of the rind by overproduction of $\mathrm{Fe}^{+3}$. Rind surface erosion produces a net loss at the rind edge, which when competing with deepening of the rind/ fresh clast interface, may result in a minimum rind thickness/age estimate. Similarly, sealing off of the rind edge by aggressive bio/microbially-generated or climatically-induced higher redox potential, thus producing a secondary Fe mineral rind cap, slows or stops the ingress of heat and moisture necessary to continue rind production (Mahaney et al., 2012a, c). Hence, age estimates, especially for deposits older than Holocene, given the effect of climatic/biogenic flux effects on clast weathering, should be taken with caution. With the Okstindan rind sequence outlined here, deposits are young enough and with clast weathering in its nascent stage, rind weathering is operating at peak efficiency unhampered by armoring effects.

To illustrate the record of extreme events incorporated into rind archives, one need only witness the effect of a cosmic airburst/impact on buried and surface clasts in two widely separated areas: Northern Andes (Mahaney et al., $2013 \mathrm{~b}$ ) and the Western Alps of France and Italy (Mahaney and Keiser, 2012; Mahaney et al., 2013a). The Andean occurrence documents melting and comminution of felsic gneiss sediment, specifically fine gravel and sand in an outwash channel overrun by Younger Dryas ice and radiocarbon dated to within the YDB (Younger Dryas Boundary) of $12.8 \mathrm{ka}$. A similar time frame is postulated (Mahaney et al., 2014) for a cosmic impact affecting Late Glacial (LG) surfaces in the upper Guil and Po catchments of France and Italy, including both surface soils at time of impact (now paleosols) and surface clasts. The paleosols contain elevated REEs significantly concentrated above crustal norms (Rudnick and Gao, 2005) and $\mathrm{Pt} / \mathrm{Pd}$ ratios equivalent to meteor impacts and concentrations of black mat sediment incorporated into the Greenland ice sheet (Petaev et al., 2013). Rinds recovered from the surface of paleosols come complete with melted out surfaces, reformed quartz recrystallized with impact, opaque carbon covering mineral surfaces, incorporated airburst forms of allochthonous and autochthonous minerals, Fe spherules to within specifications of grains recovered from other airburst sites (Firestone et al., 2007).

Paleoenvionment archives in young Neoglacial rinds are documented only by Etienne (2002) in clasts recovered from Little Ice Age deposits in Iceland, although microbe fossils within the rinds may be the product of reworking from older deposits. From experience with rinds on Mt. Kenya $(<1.5 \mathrm{ka}$ rinds), and in the Rocky Mountains of North America (rinds dated by lichen growth to $<3 \mathrm{ka}$ ) show only hydrolization effects with development of Fe oxides and hydroxides, with no microbe development.

\section{CONCLUSIONS}

Rinds comprise considerable paleoenvironmental archives whether used to determine relative age control of depos- its or as repositories containing mineral-organo-chemical records of past weathering thermodynamic processes converting rock into secondary weathering products. With the combined kinetic effects of the atmosphere, hydrosphere and biosphere acting on clastic materials over short and long time frames, the analysis of weathering rinds offers an often underused approach to research into paleoenvironmental surface systems, one that can be correlated to soil and paleosol stratigraphic approaches. Certainly, the late Neoglacial rind data archived in clasts from the Okstindan sequence suggest additional research could produce tighter age controls on glacier fluctuations. It is possible the moraines in the middle group of late Neoglacial deposits are related to the Tambora volcanic eruption of 1815 , which as a forcing mechanism would have forestalled retreat of the glacier as the LIA advance was coming to an end. With tight statistical ranges for each mean rind thickness calculation in each of the three sample groups, weathering rinds provide precise age measurements of weathering, especially in situations where lithology is normalized and some radiocarbon control modulates weathering rates.

\section{Acknowledgements}

This research was funded by Quaternary Surveys, Toronto. I gratefully acknowledge reviews by Jan Dzierżek and one anonymous reviewer.

\section{REFERENCES}

Beschel, R.E., 1950. Flechten als Altersmasstab rezenter Moranen. Zeitschrift fur Gletscherkunde und Glazialgeologie 1, 152-61.

Beschel, R., 1973. Lichens as a measure of recent moraines. Arctic and Alpine Research 5 (4), 303-309.

Bjerkgírd, T., Larsen, R., Marker, M., 1995. Regional geology of the Okstindene Area, The Rödings Fjall Nappe Complex, Nordland, Norway. Report: 95.153 based on Mo I Rana 1:50000 Map Sheet.

Birkeland, P.W., 1973. Use of relative age dating methods in a stratigraphic study of rock glacier deposits, Mt. Sopris, Colorado. Arctic. Alpine. Research 5, 401-416.

Birkeland, P.W., 1999. Soils and Geomorphology, Third Edition, Oxford, N.Y. 430 pp.

Bronk-Ramsey, C., 2005. OxCal Program v 3.10. University of Oxford Radiocarbon Unit, Oxford.

Canada Soil Survey Committee (CSSC), 1998. The Canadian System of Soil Classification. 637 NRC Research Press, Ottawa, Canada (Publ. 1646), 187 p.

Chinn, T. J. H., 1981. Use of rock weathering-rind thickness for Holocene absolute age-dating in New Zealand. Arctic. Alpine. Research 13, 33-45.

Colman, S. M., 1981. Rock-weathering rates as functions of time. Quaternary Research 15, 250-264.

Colman, S.M., Pierce, K.L., 1981. Weathering rinds on andesitic and basaltic stones as a Quaternary age indicator, western United States. U.S. Geol. Surv. Prof. Pap. 1210, 56 p.

Dixon, J.C., Campbell, S.W., Thorn, C.E., Darmody, R.G., 2006. Incipient weathering rind development on introduced machine-polished granite discs in an Arctic alpine environment, northern Sweden. Earth Surf. Processes Landf. 31, 111-121.

Dorn, R.I., 2009. Desert rock coatings. In Parsons, A.J., Abrahams, A.D. (eds) Geomorphology of desert environments (2nd ed.). New York, Springer, p. 153-186.

Earl-Goulet, J., Mahaney, W.C., Kalm, V., Sanmugadas, K., Han- 
cock, R.G.V., Milner, M.W., 1998. Middle-Holocene timberline fluctuation: influence on the genesis of Podzols (Spodosols), Norra Storfjället Massif, northern Sweden. The Holocene 8, 705-718.

Elliott, G., Worsley, P., 1999. The sedimentology, stratigraphy and 14C dating of a turf-banked solifluction lobe: evidence for Holocene slope instability at Okstindan, northern Norway. Journal of Quaternary Science 14, 175-188.

Ellis, S., 1979. Radiocarbon dating evidence for the initiation of solifluction ca. 5500 years BP at Okstindan, North Norway. Geografiska Annaler 61A, 29-33.

Etienne, S., 2002. The role of biological weathering in periglacial areas: a study of weathering rinds in south Iceland. Geomorphology 47, 75-86.

Firestone, R.B., West, A., Kennett, J.P., Becker, Bunch, T.E., Revay, Z.S., Schultz, P.H., Belgya. T., Kennett, D.J., Erlandson, J.M., Dickenson, O.J., Goodyear, A.C., Harris, R.S., Howard, G.A., Kloosterman, J.B., Lechler, P., Mayewski, P.A., Montgomery, J., Poreda, R., Darrah, T., Que Hee, S.S., Smith, A.R., Stich, A., Topping, W., Wittke, J.H., Wolbach, W.S., 2007. Evidence for an extraterrestrial impact 12,900 years ago that contributed to the megafaunal extinctions and the Younger Dryas cooling. Proc. Natl. Acad. Sci. USA 104 (41), 16016-16021.

Geological Survey of Norway, 2007. Storakersvatnet 2027 III sheet, Norges Geologiske Undersokelse 1:50 000.

Griffey, N.J., Worsley, P., 1978. The pattern of Neoglacial glacier variations in the Okstindan region of Northern Norway during the last three millennia. Boreas 7, 1-17.

Gurney, S.D., Bartsch, A., 2005. Mapping the spatial distribution of geomorphological processes in the Okstindan area of northern Norway, using geomorphic process units as derived from remote sensing and ground survey. Fennia 183 (1), 1-14.

Laustela, M., Egli, M., Frauenfelder, R., Kaab, A., Maisch, M., Haeberli, W., 2003. Weathering rind measurements and relative age dating of rock glacier surfaces in crystalline regions of the eastern Swiss Alps. In Phillips, M., Springman, S.M., Arenson, L.U. (eds) Permafrost: Proceedings of the 8th International Conference on Permafrost. Lisse, Netherlands, Swets \& Zeitlinger.

Lebedeva, M.I., Fletcher, R.C., Balashov, V.N., Brantley, S. L., 2007. A reactive diffusion model describing transformation of bedrock to saprolite. Chemical Geology 244, 624-645.

Mahaney, W.C., 1973. Neoglacial chronology in the Fourth of July Cirque, central Colorado Front Range. Bulletin Geological Society America 83 (11), 161-170.

Mahaney, W.C., 1978. Late Quaternary soil stratigraphy in the Wind River Mountains, western Wyoming. In Mahaney, W.C. (ed.) Quaternary Soils. Geo-Abstracts, Norwich, UK, 223264.

Mahaney, W.C., 1987. Tentative Growth Curve for Rhizocarpon geographicum s. I. in Stroud Basin, Wind River Range, Western Wyoming. Northwest Science 61 (1), 13-19.

Mahaney, W.C., 1990. Ice on the Equator. Wm Caxton Ltd., Ellison Bay, Wi., 386 pp.

Mahaney, W.C., 2015. Pedological Iron/Al Extracts, Clast Analysis, and Coleoptera from Antarctic Paleosol 831: Evidence of a Middle Miocene or Earlier Climatic Optimum. Journal Geology 123, 113-132.

Mahaney, W.C., Spence, J.R., 1984. Late Quaternary deposits, soils, chronology and floristics, Jaw Cirque area, Central Teton Range, W. Wyoming. American Journal of Science 284, 1056 1081 .

Mahaney, W.C., Kalm, V., 2012. Topographic and bioclimatic controls on soil/paleosol morphogenesis in the Norra Storfjället Mountains, Sweden. Geomorphology 173/174, 43-51.
Mahaney, W.C., Keiser, L., 2012. Weathering rinds-unlikely host clasts for an impact-induced event. Geomorphology 184, 74-83.

Mahaney, W.C., Hancock, R.G.V., 2015. Holocene soils/paleosols in the Okstindan Mountains, Nordland: stratigraphy and extractable Fe and Al. Geografiska Annaler 97 (2), 355-373.

Mahaney, W.C., Schwartz, S., 2016. Paleoclimate of Antarctica Reconstructed from Clast Weathering Rind Analysis. Palaeogeography, Palaeoclimatology, Palaeoecology 446, 205-212.

Mahaney, W.C., Hancock, R.G.V., Sanmugadas, K., 1999. Extractable $\mathrm{Fe}$ and $\mathrm{Al}$ soils in the middle Teton chronosequence, western Wyoming, U.S.A., Zeitschrift für Geomorphologie 43 (3), 393-407.

Mahaney, W.C., Krinsley, D.H., Allen, C.C.R., Langworthy, K., Ditto, J., Milner, M.W., 2012a. Weathering Rinds: Archives of Paleoenvironments on Mount Kenya, East Africa. Journal Geology 120 (6), 591-602.

Mahaney, W.C., Krinsley, D.H., Allen, C.C.R., 2012b. Bio-mineralization of weathered rock rinds: examples from the lower Afroalpine zone on Mount Kenya. Geomicrobiology Journal $30,411-421$.

Mahaney, W.C., Dohm, J.M., Fairen, A., 2012c. Weathering rinds on clasts: examples from Earth and Mars as short and long term recorders of paleoenvironment. Journal of Planetary and Space Sciences 73, 243-253.

Mahaney, W.C., Keiser, L., Krinsley, D.H., Pentlavalli, P., Allen, C.C.R., Somelar, P., Schwartz, S., Dohm, J.M., Dirzowsky, R., West, A., Julig, P., Costa, P., 2013a. Weathering rinds as mirror images of palaeosols: examples from the Western Alps with correlation to Antarctica and Mars. Journal of the Geological Society $170,833-847$.

Mahaney, W.C., Keiser, L., Krinsley, D., Kalm, V., Beukens, R., West, A., 2013b. New Evidence from a Black Mat Site in the northern Andes supporting a cosmic impact 12,800 Years Ago. Journal Geology 121, (6), 591-602.

Mahaney, W.C., Krinsley, D.H., Allen, C.C.R., Milner, M.W., Batchelor, D., LeCompte, M., Kelleher, B., O'Reilly, S., 2013c. Reassessment of the microbial role in $\mathrm{Mn}-\mathrm{Fe}$ nodule genesis in Andean paleosols. Geomicrobiology Journal 32, $27-41$.

Mahaney, W.C., Keiser, L., Krinsley, D.H., West, A., Dirszowsky, R., Allen, C.C.R., Costa, P., 2014. Recent Developments in the Analysis of the Black Mat Layer and Cosmic Impact at $12.8 \mathrm{ka}$. Geografiska Annaler 96 (1), 99-111.

Nelson, R.L., 1954. Glacial geology of the Frying Pan River Drainage, Colorado. Journal Geology 62, 325-343.

National Soil Survey Center (NSSC), 1995. Soil Survey Laboratory Information Manual. Soil Survey Investigations Report no. 45, version 1.00, U.S.D.A., pp. 305.

Oguchi, C.T., 2013. Weathering Rinds: Formation Processes and Weathering Rates. In Shroder, J.F. (ed.) Treatise on Geomorphology vol. 4, 98-110. San Diego: Academic Press.

Oyama, M., Takehara, H., 1970. Standard Soil Color Charts. Japan Research Council for Agriculture, Forestry and Fisheries.

Pelt, E., Chabaux, F., Innocent, C., Navarre-Sitchler, A.K., Sak, P. B., Brantley, S.L., 2008. Uranium thorium chronometry of weathering rinds: rock alteration rate and paleo-isotopic record of weathering fluids. Earth Planetary Sci. Lett. 276, 98-105.

Petaev, M.I., Huang S., Jacobsen, S.B., Zindler, A., 2013. Large Pt anomaly in the Greenland ice core points to a cataclysm at the onset of Younger Dryas. Proc. Natl. Acad. Sci. USA 110(32), 12917-12920.

Reimer, P.J., Baillie, M.G.L., Bard, E., Bayliss, A., Beck, J.W., Bertrand, C.J.H., Blackwell, P.G., Buck, C.E., Burr, G.S., Cutler, K.B., Damon, P.E., Edwards, R.L., Fairbanks, R.G., Friedrich, M., Guilderson, T.P., Hogg, A.G., Hughen, K.A., Kromer, B., McCormac, G., Manning, S., , Ramsey, C.B., Reimer, R.W., Remmele, S., Southon, J.R., Stuiver, M., Talamo, S., 
Taylor, F.W., Taylor, F.W., van der Plicht, J., Weyhenmeyer, C.E., 2004. IntCal04 terrestrial radiocarbon age calibration, 0-26 cal kyr BP. Radiocarbon 46, 1029-1059.

Rudnick, R.L., Gao, S., 2005. Composition of the continental crust. In Rudnick, R.L. (ed.) The Crust: Treatise on Geochemistry. Elsevier, Amsterdam, 1-64.

Runemark, H., 1956. Studies in Rhizocarpon . I. Taxonomy of the yellow species in Europe. Opera Botanica 2, 1-152.

Sak, P. B., Fisher, D.M., Gardner, T.W., Murphy, K., Brantley,
S.L., 2004. Rates of weathering rind formation on Costa Rican basalt. Geochim. Cosmochim. Acta 68, 1453-1472.

Sharp, R.P., 1969. Semiquantitative differentiation of glacial moraines near Convict Lake, Sierra Nevada. California. Journal Geology 77, 68-91.

Spence, J., Mahaney, W.C., 1988. Growth and ecology of Rhizocarpon Section Rhizocarpon on Mt. Kenya, East Africa. Arctic and Alpine Research 20 (2), 237-242. 